\title{
Experimental Validation of Single Phase Series Active Power Filter Using Fuzzy Control Technique
}

\author{
Abdallah Ben Abdelkader ${ }^{1}$, Othmane Abdelkhalek ${ }^{2}$, Ahmed Allali ${ }^{3}$ \\ ${ }^{1,3}$ Département de Génie Electrique, Faculté de l'électrotechnique, Université des Sciences et la \\ Technologie d'Oran Mohamed Boudiaf(USTO-MB), BP 1505, El M'naouer, 31000, Oran, Algeria \\ ${ }^{2}$ Smart Grids and Renewable Energies Lab. Department of Electrical Engineering TAHRI \\ Mohammed University of Bechar, Algeria
}

\begin{tabular}{l}
\hline \hline Article Info \\
\hline Article history: \\
Received Dec 17, 2017 \\
Revised Jan 18, 2018 \\
Accepted Feb 2, 2018 \\
\hline
\end{tabular}

Keyword:

Fuzzy controller

Harmonic voltage

PI controller

Series active power filter

Voltage sag/ swell

\begin{abstract}
The aim of this paper is illustrating and exposing the performance of a Series Active Power Filter (SAPF) with PI controller and Fuzzy controller within simulation and experimental validations. This performance is best manifested in compensating the sags and the swells voltages and in eliminating the harmonic voltage and regulate the terminal voltage of the load by injecting a voltage component in series with source voltage which is increased or decreased from the source voltage, hence, maintaining the load side waveforms as pure sinusoidal. The control method used in this work is not so complex and it is based on a phase locked loop (PLL) that is used to control the active filter. It is valid only in the phase system. The efficiency of the method suggested is affirmed through simulation results by MATLAB/Simulink® and some prototypes experiments. These results shows the capability of the proposed prototypes.
\end{abstract}

Copyright () 2018 Institute of Advanced Engineering and Science. All rights reserved.

\section{Corresponding Author:}

Abdallah Ben Abdelkader,

Département de Génie Electrique, Faculté de l'électrotechnique,

Université des Sciences et la Technologie d'Oran Mohamed Boudiaf(USTO-MB), BP 1505, El M'naouer, 31000, Oran, Algeria

Email: webusto-mb@univ-usto.dz

\section{INTRODUCTION}

The quality of energy depends on the loads and their sensitivity to supply voltages variations. The poor quality of electrical energy is not only the cause for the loss to the Economic customers (factories, enterprises, etc) in production and storage of raw materials but also to the companies that produce the electrical energy [1-2-3].

The proliferation of electronic equipment pollutes electrical distribution networks with harmonics, deforming the waveforms of the voltage and the current. Simultaneously, the consequence that the user oversees is that the impact on the electrical equipment's electrical installations of excessive heating and accelerated ageing [4-3]. This phenomenon has another influence on the application's functioning; in addition, it does a direct persuasion on the feeding sensitive loads. Lastly, it has an impact on the electrical power available in the installation because there is an overconsumption owing to harmonics [4-3].

Thanks to the perfection of technological electronics, new norms and control strategies were burst on the energy's quality domain to filtrate the turbulent voltage for that reason to improving the electrical energy's distribution. Active filters (AFS) have been extensively used as one solution to harmonic distortion $[5,6,7,9]$. The electrical turbulent reduce and damage the electrical equipment connected to the system. There are many systems that correct this problematic. Among these systems, we find the SAPF that improves the power quality via correcting the unbalanced and harmonic voltages and adjust them in association with PI or Fuzzy controller. 


\section{DESCRIPTION SYSTEM}

The system is made up of three main blocks: the first is the programmable voltage source, the second is the Sensitive load (Sensitive Medical equipment) with a single phase, the third is a series active filter; it consists of single phase PWM voltage source inverter injecting compensation voltage through one transformer. The output of inverter is connected to a second order filter to eliminate high frequency caused by the switching action of the inverter. The secondary winding of each transformer is connected in series with power supply as shown in Figure 1.

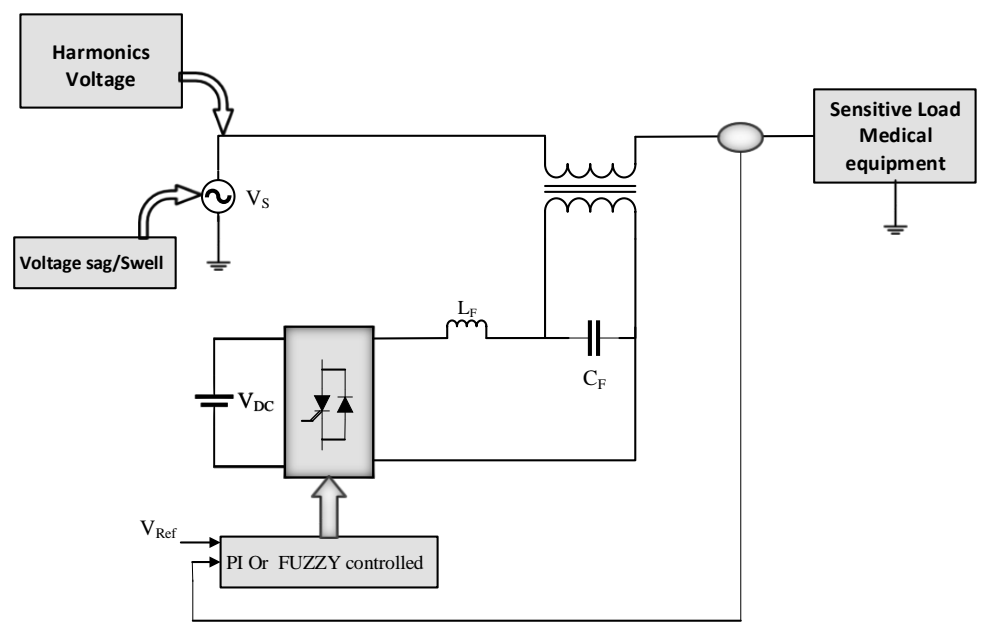

Figure 1. Series active power filter configuration

\section{RESULTS AND ANALYSIS}

In this paper a simple control method is proposed and its effectiveness at frequent instances is evaluated through simulation. Voltage distortion and voltage sag and swell are simulated and compensate by using series active filter with simple control method. Also, a single phase locked loop is used to extract attitude data. Phase locked loop in this paper is a good choice for such structures and manipulate method is easy and robust at exceptional ways.

$V_{a f}(t)=V_{s}(t)-V_{i n j}(\mathrm{t})$

Where $V_{\text {inj }}(t)$ voltage at load terminal, produced voltage byactive filter is injected in series by using device through a transformer. Because in such instances voltage high-quality is important, the dc voltage of active filter is supplied through a low power diode rectifier. Figure 2 shows the control approach of active filter. Reference voltage $V_{a f}(t)$ is utilized to a pulse width modulator to produce it by way of active filter.

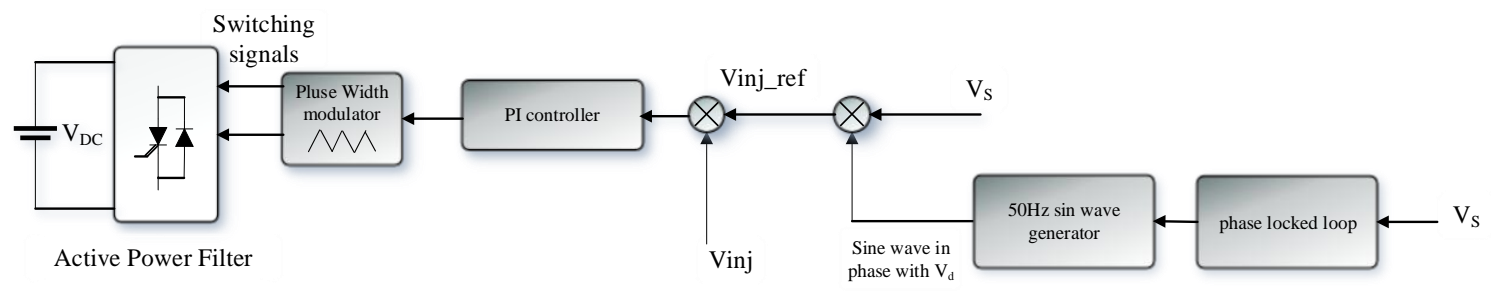

Figure 2. Active filter controller

Tables and Figures are presented center, as shown below and cited in the manuscript. 


\section{PHASE LOCKED LOOP}

Synchronization is one of the most essential troubles in the control of power electronics tools connected to the grid. Most of the power converters control algorithms use the phase size of the grid fundamental component. The faster and extra correct this measurement is, the higher the technology of reference signals results, and consequently a more efficient control is carried out [5-8-10-11]. The PLL block shown in Figure 3 is formed by:

1- $\quad$ the phase detector (PD)

2- $\quad$ the loop filter (LF)

3- the voltage controlled oscillator (VCO)

It is a non-linear circuit that its input signal synchronizes with its output signal in frequency as well as in phase. When the PI uses the LF, the PLL accomplishes a zero stable state. The input signal of equation (1) is considered to analyze the PLL dynamics:

$$
v_{i}=1 \cdot \sin \left(\omega_{i} t+\theta_{i}\right)+f\left(3 \omega_{i}, 5 \omega_{i}, 7 \omega_{i} \ldots\right)
$$

As it is plained, the used unit is the PU. The fundamental component amplitude value is $1 \mathrm{PU}$. The wave at the PD output is:

$v_{i} \cdot \cos \left(\omega_{0} t+\theta_{0}\right)=\frac{1}{2} \sin \left(\omega_{i} t+\theta_{i}-\omega_{0} t-\theta_{0}\right)+\frac{1}{2} \cos \left(\omega_{i} t+\theta_{i}-\omega_{0} t-\theta_{0}\right)+f\left(2 \omega_{i}, 4 \omega_{i}, 6 \omega_{i} \ldots\right)$

The PLL can be linearized, assuming that the PLL is locked in steady-state; under such a situation $\omega_{\mathrm{i}}=\omega_{0}$ and $\theta_{\mathrm{i}}=\theta_{0}$ so:

$v_{i} \cdot \cos \left(\omega_{0} t+\theta_{0}\right) \sim=\frac{1}{2} \sin \left(\theta_{i}-\theta_{0}\right)+\frac{1}{2} \cos \left(2 \omega_{i} t+2 \theta_{i}\right)+f\left(2 \omega_{i}, 4 \omega_{i}, 6 \omega_{i} \ldots\right)$

Equation (2) shows that in steady-state the wave has a small dc signal with the phase error information $\left(\theta_{\mathrm{e}}\right)$, a high second harmonic and other even harmonic components. The LF is a low pass filter, which should be tuned to control $\left(\theta_{0}\right)$ and cancel harmonic components so the PLL is equivalent to the linear system. [11]

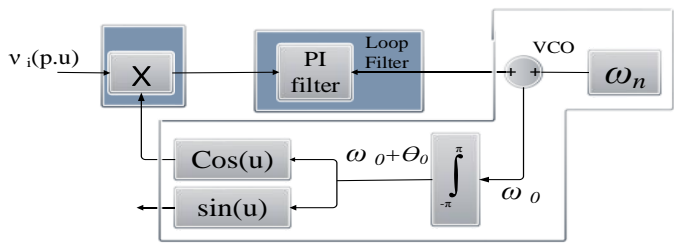

Figure 3. Phase locked loop [11]

\section{PI CONTROLLER}

If measuring the reference voltage and the RMS value of the terminal voltage, the end result is the input of the PI controller, which operates error signal. Whereas the output is considered as the angle which leads to the PWM signal generator. The PWM generator then makes the pulse signals to the IGBT gates of voltage source converter (VSC). The PI controller can't react torough changes in the error signal $(\varepsilon)$, it analyses the instantaneous value of the error signal left out the rise and fall of the error. Mathematically, this practice is called the derivative error signal and characterized as $\Delta \varepsilon$.

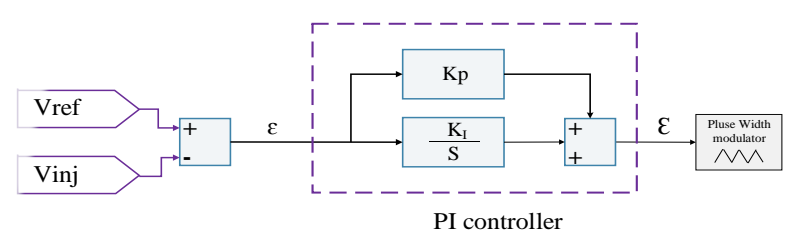

Figure 4. PI controller with PWM

Experimental Validation of Single Phase Series Active Power Filter Using .... (Abdallah Ben Abdelkader) 
Here the values of proportional and integral gain taken as $\mathbf{K}_{\mathbf{p}}=\mathbf{7 , 2}, \mathbf{K}_{\mathrm{i}}=\mathbf{3 3}$.

\section{FUZZY CONTROLLER}

The fuzzy controller consists of the error voltage of the load phase voltage, and the alternation of voltage (previous error - voltage error). Linguistically, these two inputs contain seven Gaussian membership functions which helped to accomplish the 49 'IF THEN' rules. Using the Centroid method, the combination of the output of fuzzy controller with the active component of load voltage is recovered. Table (1) shows Inference matrix of fuzzy rules.

Table 1. Rule Base for Fuzzy Controller

\begin{tabular}{|c|c|c|c|c|c|c|c|}
\hline$\frac{\operatorname{de}(\mathrm{n})}{\mathrm{e}(\mathrm{n})}$ & NB & NM & NS & ZE & PS & PM & PB \\
\hline NB & $\mathrm{NB}$ & $\mathrm{NB}$ & NB & NB & NM & NS & $\mathrm{ZE}$ \\
\hline NM & NB & NB & NB & NM & NS & NZ & PS \\
\hline NS & NB & NB & NM & NS & NZ & PS & PM \\
\hline ZE & NB & $\mathrm{NM}$ & NS & ZE & PS & PM & PB \\
\hline PS & NM & NS & ZE & PS & PM & PB & PB \\
\hline PM & NS & ZE & PS & PM & PB & PB & PB \\
\hline PB & ZE & PS & PM & PB & PB & PB & PB \\
\hline
\end{tabular}

The fuzzy controller has benefited of Mamdani Fuzzy system. The functions which are named as; negative big (NB), negative medium (NM), negative small (NS), zero (Z), positive big (PB), positive medium (PM) and positive small (PS), structure the variable input and output of the fuzzy logic controller. The inputs variables are presented in Figure 6, and output variable are shown in Figure 7.
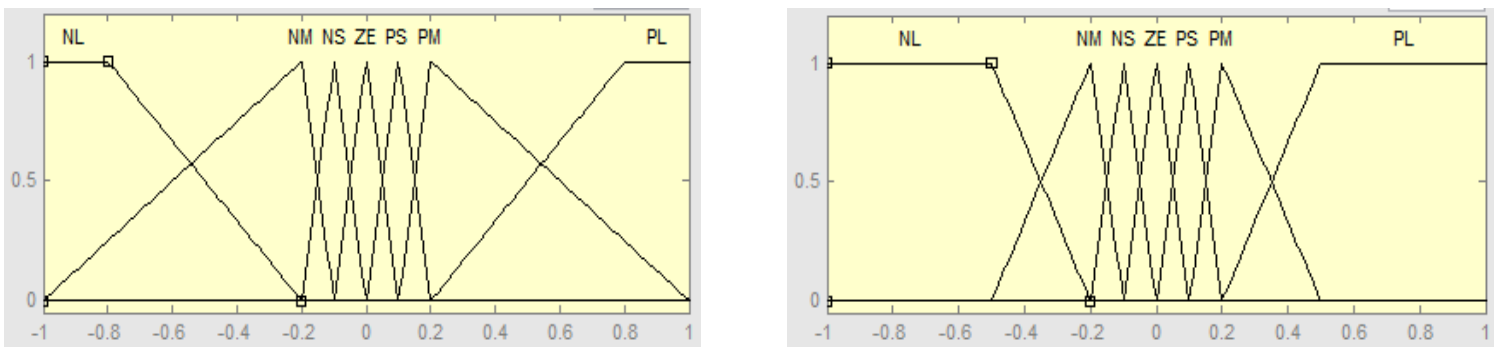

Figure 6. Inputs variables e,de

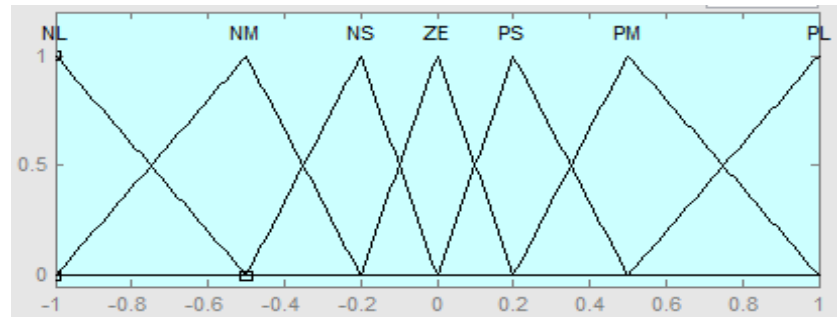

Figure 7. output variable cde

The mamdani type fuzzy logic controller is used; the max-min inference method is applied in this study. The relation surface between inputs (e, de) and output (cde) of FLC is shown in Figure 8. In this section, it is explained the results of research and at the same time is given the comprehensive discussion. Results can be presented in figures, graphs, tables and others that make the reader understand easily [2], [6]. The discussion can be made in several sub-chapters [5]. 


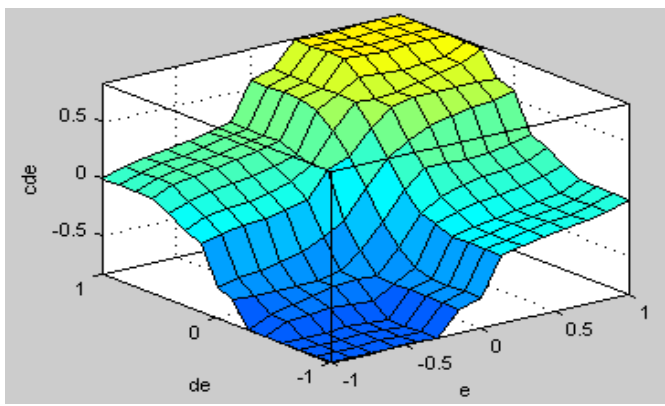

Figure 8. The relation surface between inputs and output of FLC

The advantages of fuzzy controllers are that they do not require an accurate mathematical model; it can work with imprecise inputs, can handle non-linearity, and are more robust than conventional controllers.

\section{SIMULATION AND EXPERIMENTAL RESULTS}

\subsection{Simulation results}

The PI and Fuzzy controller simulations are developed in MATLAB \Simulink. Many simulation tests have been performed with the flowing electrical parameters as mentioned in Table (2). and the simulation diagram is shown in Figure 9.

Table 2. Electrical Parameters

\begin{tabular}{cc}
\hline Source voltage fréquence $f$ & $50 \mathrm{~Hz}$ \\
Source voltage Vs & $5,7 \mathrm{v} \mathrm{rms}$ \\
Load resistanceRL & $12.3 \Omega$ \\
CF (LC filter) & $1 \mathrm{nF}$ \\
LF (LC filter) & $9 \mathrm{mH}$ \\
Transformer & $12 \mathrm{~V} / 230 \mathrm{~V} 1 \mathrm{kVA}$ \\
dc-bus capacitor C, voltage & $22000 \mathrm{uF}, \mathrm{vdc}=75 \mathrm{v}$ \\
reference vdc & $\mathrm{Kp}=7,2-\mathrm{Ki}=33$ \\
Kp,Ki Simulation results & $\mathrm{Kp}=8,8-\mathrm{Ki}=4,24$ \\
Kp,Ki Experimental results
\end{tabular}

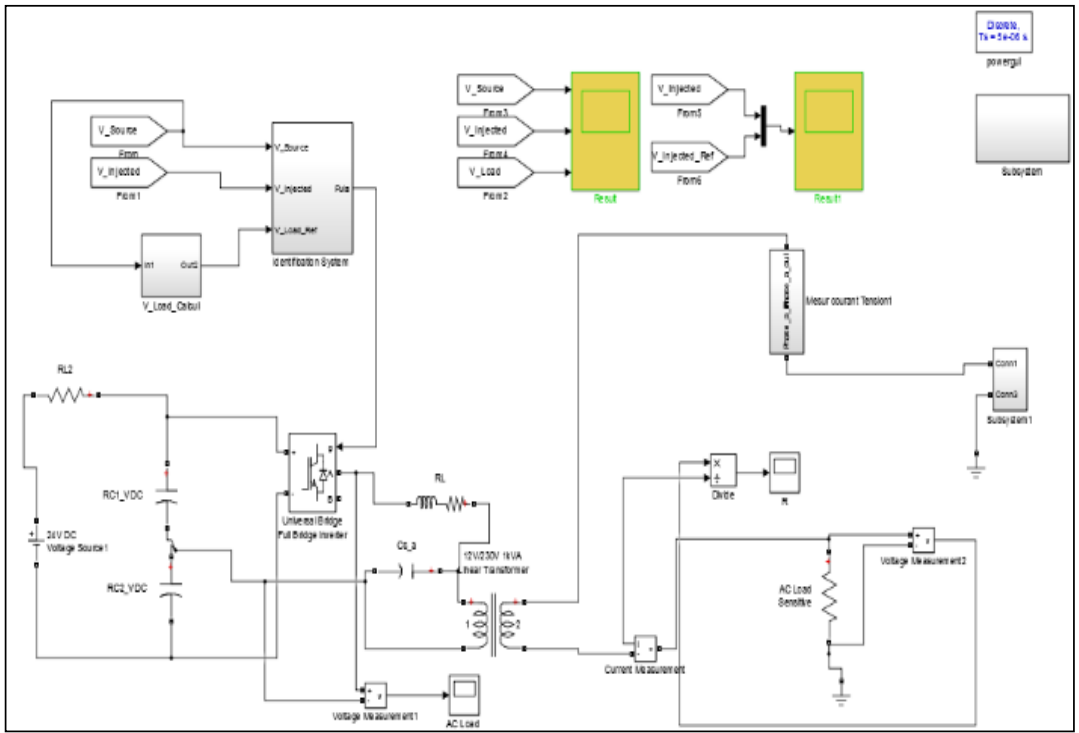

Figure 9. Simulation diagram of the system 


\subsubsection{PI controller and fuzzy controller simulation results}

\subsubsection{Case of the harmonics voltage}
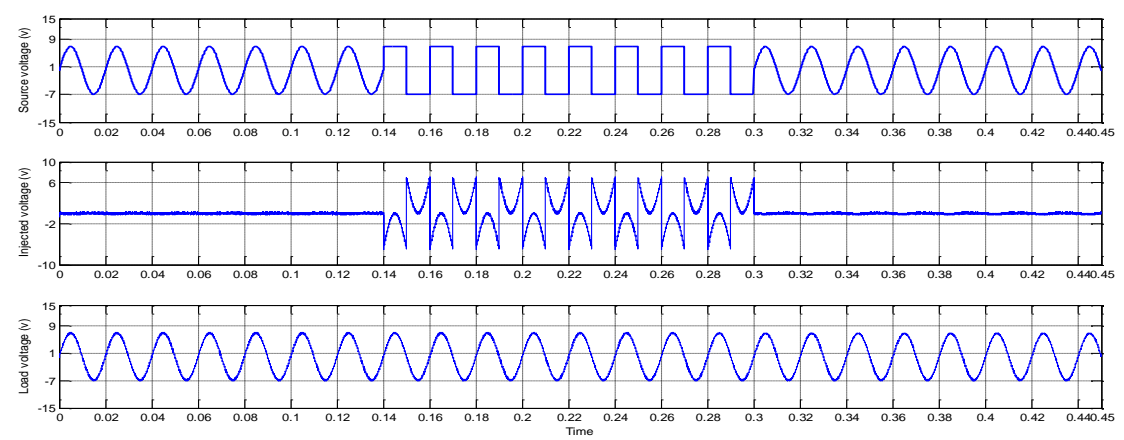

Figure 10. Simulation voltage waveformes for PI Controller
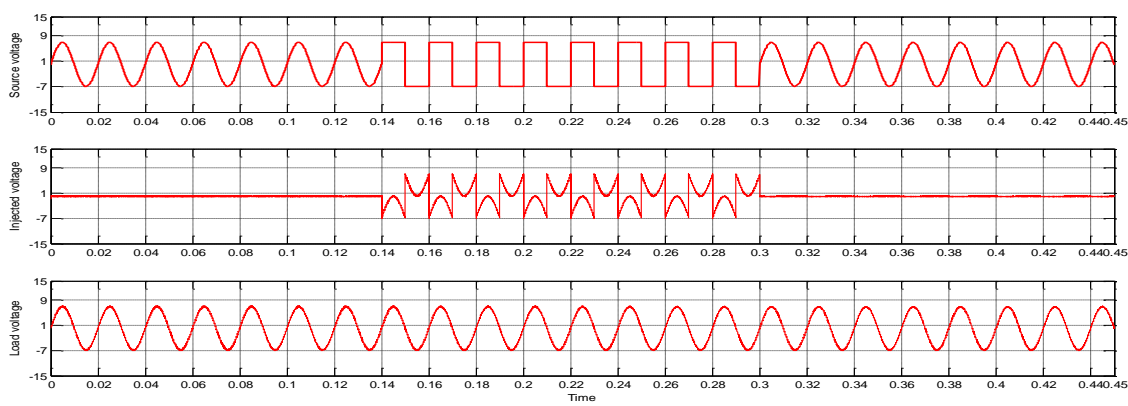

Figure 11. Simulation voltage waveformes for Fuzzy Controller

As can be seen in Figure 10 and Figure 11, for the both cases, the series active power filter has successfully compensated the voltage harmonics which it has a total harmonic distortion (THD) of $48.23 \%$ and the fundamental voltage amplitude is $6.68 \mathrm{~V}$ (peak) this voltage deformation has been well compensated through the SAPF, which the THD value becomes $2.45 \%, 5.71 \mathrm{~V}$ (Figure 12) and 1.98\%, 3.96V (Figure 13) for the case of PI end Fuzzy controller respectively.

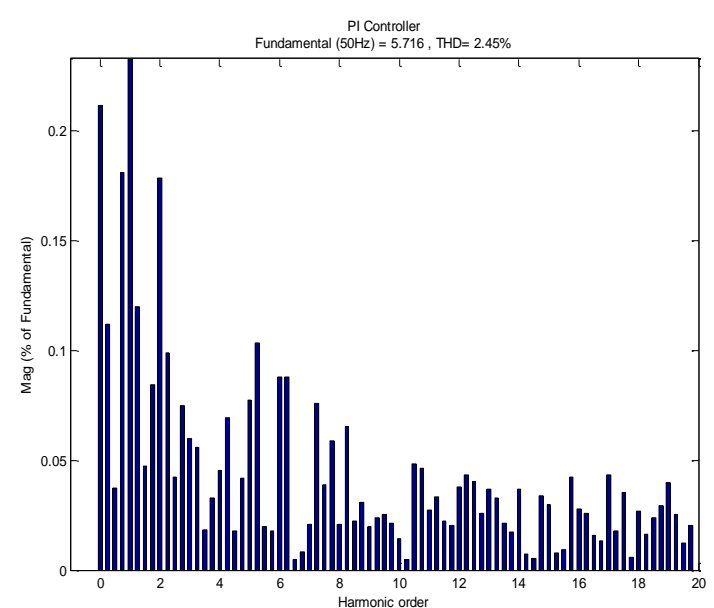

(1)

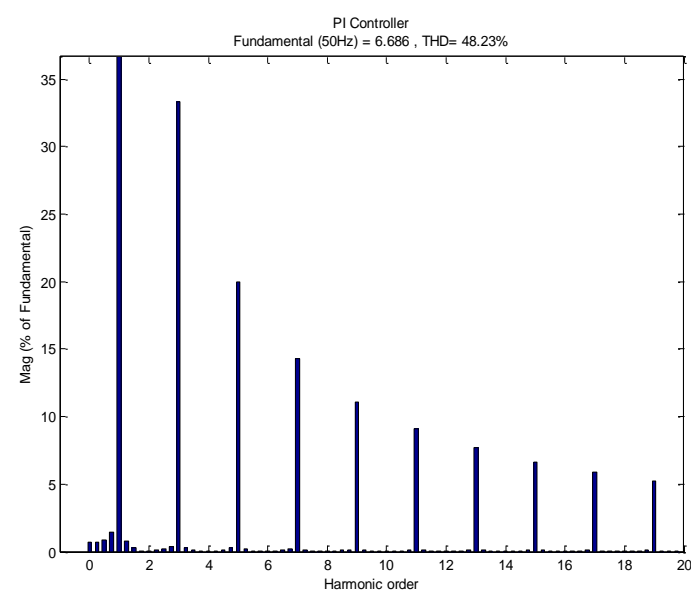

(2)

Figure 12. Spectral analysis for PI controller of the source voltage (1) and load voltage (2). 


\subsubsection{Case of the voltage sag}
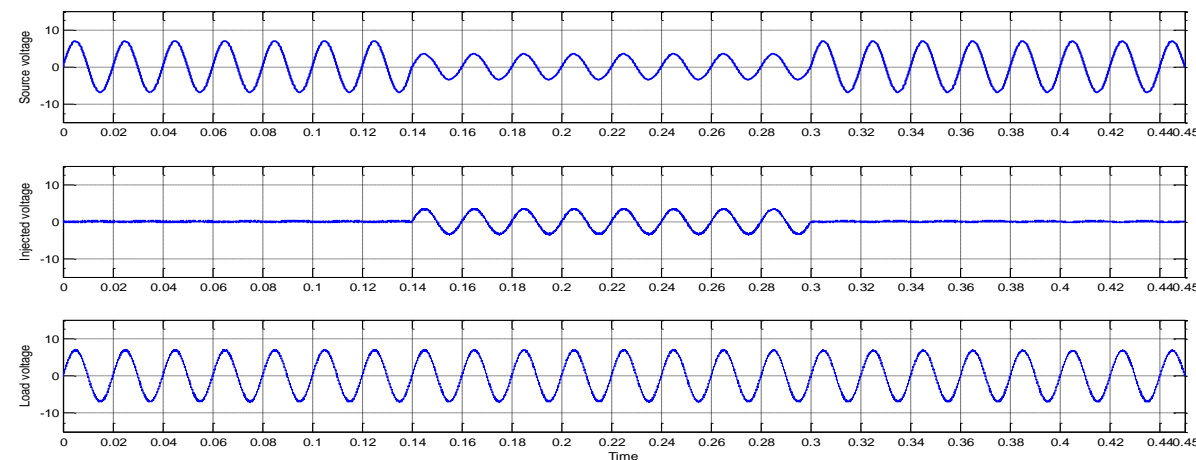

Figure 14. Simulation voltage waveformes for PI Controller
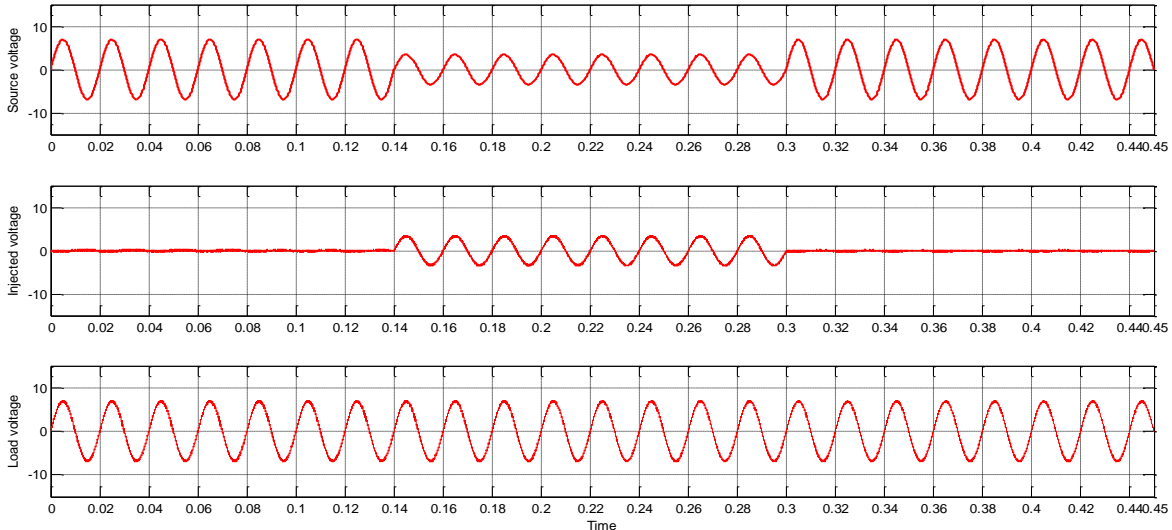

Figure 15. Simulation voltage waveformes for fuzzy controller

The Figures 14 and 15 show the phase voltage source with a 50\% sag application between $0.14 \mathrm{~s}$ and $0.3 \mathrm{~s}$, the series injected voltage, the load corrected voltage respectively for the two controllers. The Sags phenomenon's was simulated by a programmable voltage source which has the following parameters: RMS voltage $\mathrm{V}_{\mathrm{s}}=3.43 \mathrm{v}$. We notice that the load voltage $6.871 \mathrm{v}$ does not affected during this case because the Series Active Power Filter(SAPF) injects the missing voltage. The two controllers give almost same results.

\subsubsection{Case of the voltage swell}
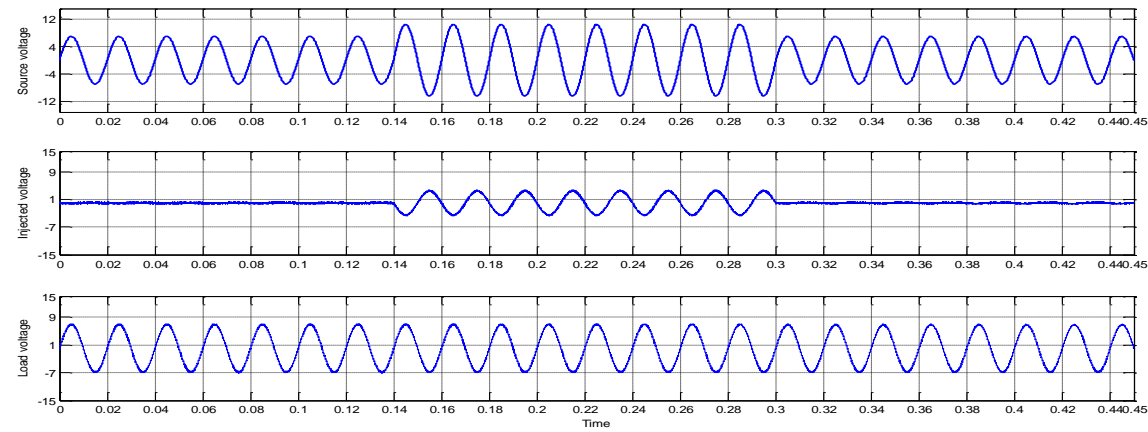

Figure 16. Simulation voltage waveformes for PI Controller 

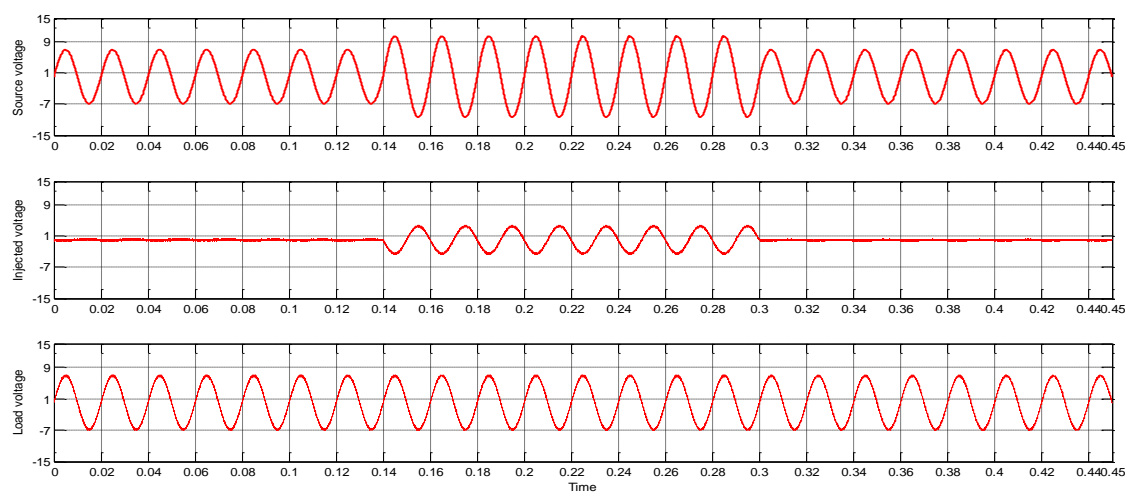

Figure 17. Simulation voltage waveformes for fuzzy controller

From the Figure 16 and 17, we can see the voltage source with a 50\% swell application between $0.14 \mathrm{~s}$ and $0.3 \mathrm{~s}$, the series injected voltage, the load corrected voltage respectively for the PI and Fuzzy controllers respectively. The applied swell voltage has the following parameters: RMS voltage $\mathrm{V}_{\mathrm{s}}=10.30 \mathrm{v}$. We notice that the load voltage 6.871v does not affected during this case because the Series Active Power Filter (SAPF) injects the missing voltage in phase oppsion.

\subsection{Experimental results}

In order to validate the simulation results of the proposed control methodes used for the Series Active Power Filter an experimental test bench designed under a dSPACE card 1104 platform from Texas instruments with a TMS32F240 DSP, inserted in a PC Pentium enabling automatic implementation of control algorithms directly from Matlab / Simulink MT as showed in the Figure 18. The prototype is realized within the Smart Grids \& Renewable Energies Laboratory (SGRE-Lab) of TM university of Bechar, Algeria. The electrical parameters are identical to those of the simulation parameters shown in Table (2)

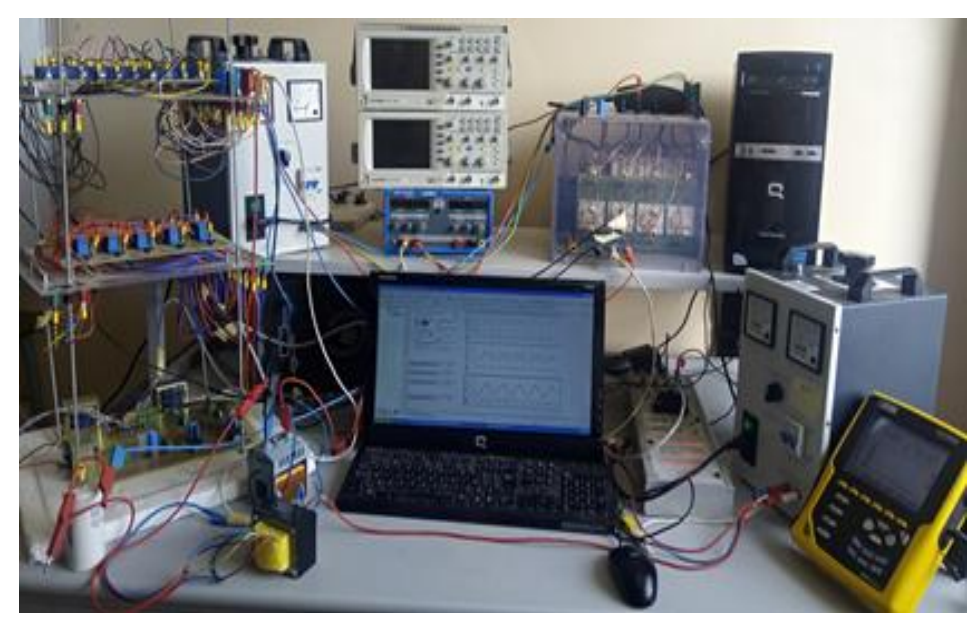

Figure 18.Experimental test banshee

The experimental test bench consists essentially of: a voltage inverter, one inductor, an injection transformer, Hall current and voltage sensors. Lenear load, and programmed source 


\subsubsection{PI controller and fuzzy controller} 7.2.1.1. Case of the Harmonics voltage
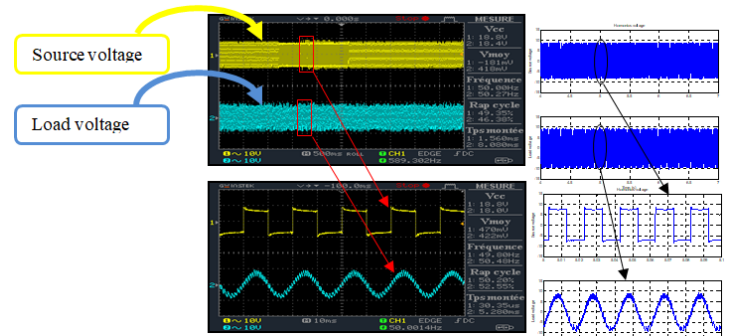

\section{has}
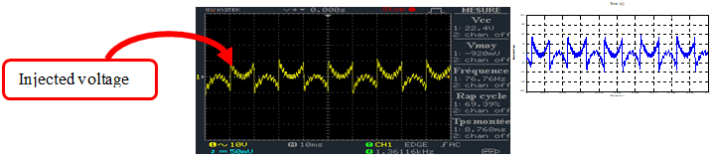

Figure 19. Experimental voltage waveformes for PI Controller

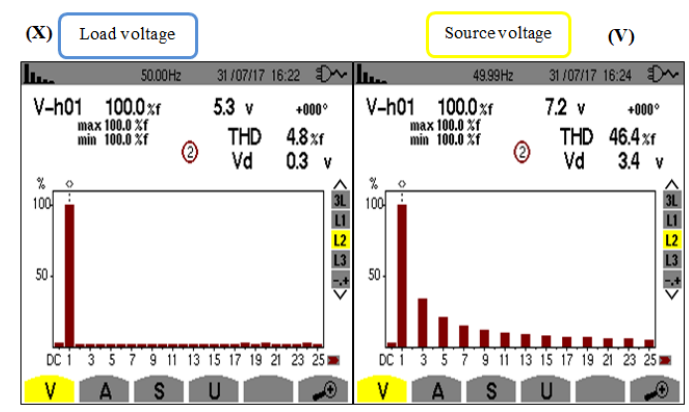

Figure 21.Spectral analysis of the source voltage and load voltage for Pi Controller

\subsubsection{Case of a voltage sag}
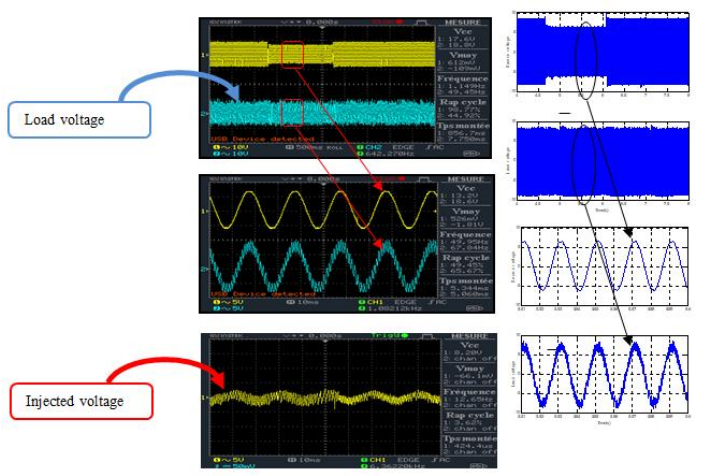

Figure 23. Experimental voltage waveformes for PI Controller

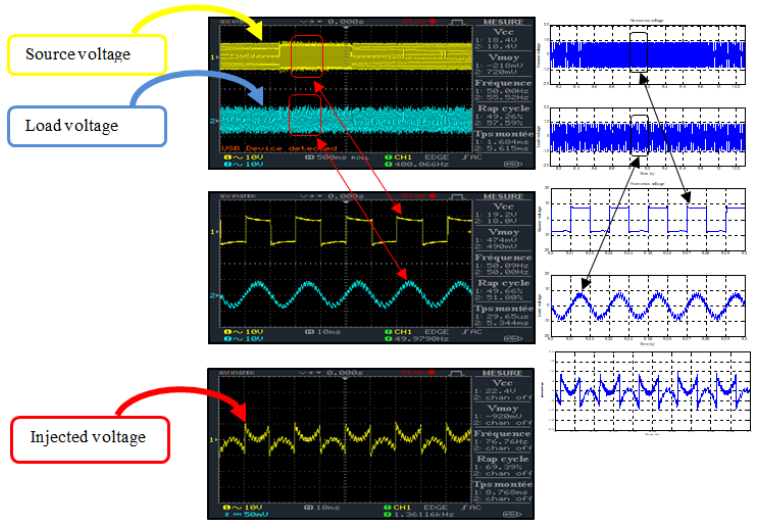

Figure 20. Experimental voltage waveformes for Fuzzy Controller

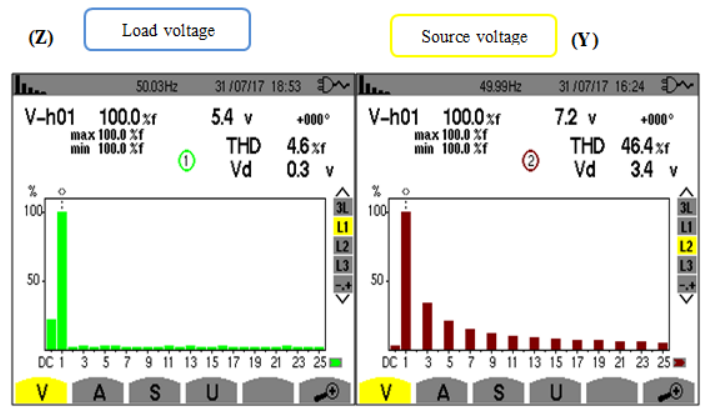

Figure 22.Spectral analysis of the source voltage and load voltage for Fuzzy Controller

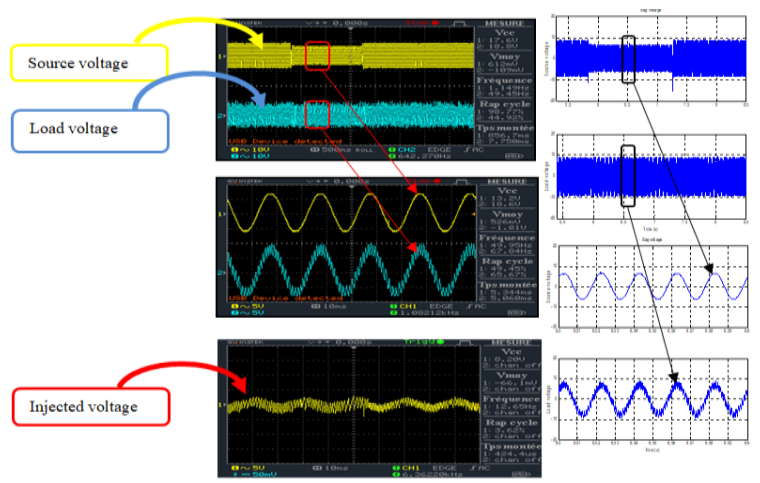

Figure 24. Experimental voltage waveformes for fuzzy controller 


\subsubsection{Case the swell voltage}

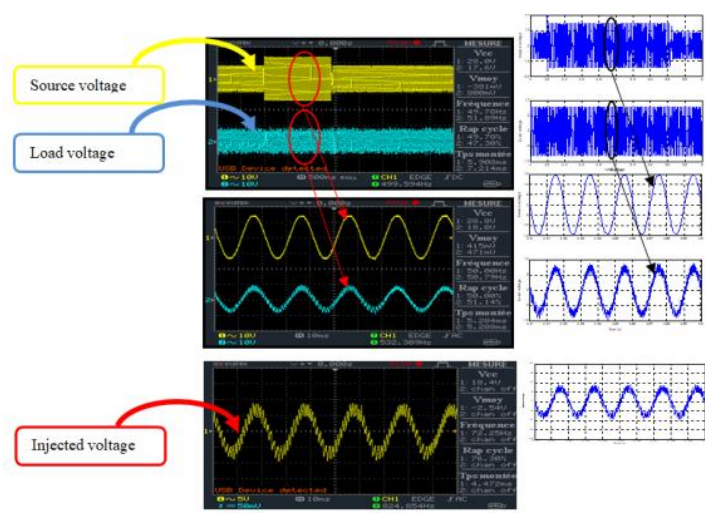

Figure 25. Experimental voltage waveformes for PI controller

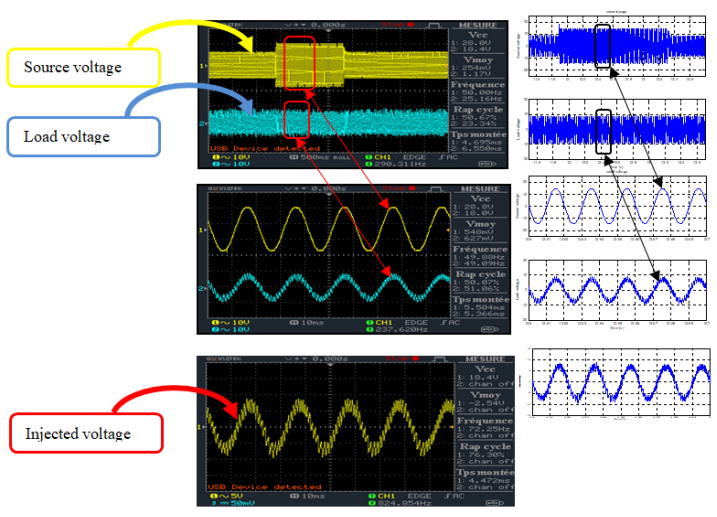

Figure 26. Experimental voltage waveformes for fuzzy controller

The proposed control algorithems are implemented on real time at $15 \mathrm{kHz}$ of PWM switching gates. The load is concedered constant and lineare. The SAPF is capable of cleaning up the load-side from voltage harmonics caused by the grid. The variation in the source voltage is obtained by connecting or disconnecting a parallel distoreded voltage inverter witch the harmonics voltage is applied between $t=5.6 \mathrm{~s}$ and $\mathrm{t}=6.3 \mathrm{~s}$ with a THDv equals $46.4 \%$ (Figure 20). Thus, use of a high polluted voltage can be a strong challenge to the enhanced algorithm in steady state. After filtering, the SAPF compensates the harmonic voltage by reducing them less than $4.8 \%$ and $4.6 \%$ respectlly for the PI and the Fuzzy controller (Figure 22) which both respect the IEEE 519 standard. The (Figure 24) and (Figure 25) show the phase voltage source with a sag of $30 \%$ applicated between $5.6 \mathrm{~s}$ and $6.3 \mathrm{~s}$. As can be seen for the both cases, the SAPF has successfully compensated the voltage sag. As shown in the (Figure 25) and 26 a $30 \%$ voltage swell is applied during a $0.7 \mathrm{~s}$, the SAPF has effectively compensated the voltage swell for the both used methodes.

Table 3. Comparison Between Simulation Results and Experimental Results

\begin{tabular}{ccccc}
\hline & \multicolumn{2}{c}{ PI controller } & \multicolumn{2}{c}{ Fuzzy controller } \\
\cline { 2 - 5 } & $\begin{array}{c}\text { THD (before } \\
\text { compensation) }\end{array}$ & THD (after compensation) & $\begin{array}{c}\text { THD (before } \\
\text { compensation) }\end{array}$ & $\begin{array}{c}\text { THD (after } \\
\text { compensation) }\end{array}$ \\
\cline { 2 - 5 } $\begin{array}{c}\text { Simulation } \\
\text { results }\end{array}$ & $48,23 \%$ & $2,45 \%$ & 48,23 & $1,98 \%$ \\
$\begin{array}{c}\text { Experimen } \\
\text { tal results }\end{array}$ & $48,4 \%$ & $4,8 \%$ & $48,4 \%$ & $4,6 \%$ \\
\hline
\end{tabular}

\section{CONCLUSIONS}

In this paper, a comparaison between two control starategies applied on series active power filter is presented. The main objective of the proposed control strategies is to achive quasi-sinusoidal load voltage. Simulation and experimental results have confirmed excellent performance of the prposed Fuzzy and PI controllers, even in transient and steady states situation. It is notable that, the simulation and experemantal results are very close.

\section{ACKNOWLEDGEMENTS}

The authors would like to thank the Laboratory of the Smart Grids \& Renewable Energies of Béchar (SGRE), Algeria for funding this research project.

\section{REFERENCES}

[1] Fatiha Mekri, Mohamed Machmoum, BenyounesMazari Nadia AitAhmed, "Determination of Voltage References for Series Active Power FilterBased on a Robust PLL System,” IEEE Int. Symposium on Ind. Elec., ISIE2007, Jun. 2007 . 
[2] Yuan Chang, Liu Jinjun, Wang Xiaoyu, Wang Zhaoan, "A Novel Controlof Series Active Power Filter without Harmonics Detection,” Power Elec.Specialists Conf., 2007. PESC 2007, Jun. 2007.

[3] M. Zadehbagheri,R Ildarabadi, M.Baghaei nejad, T. Sutikno "A New Structure of Dynamic Voltage Restorer Based on Asymmetrical $\Gamma$-source Inverters to Compensate Voltage Disturbances in Power Distribution Networks" International Journal of Power Electronics and Drive System (IJPEDS), Vol. 8, No. 1, March 2017, pp. 344 359

[4] A. Ramos, I. Nuez and V. Feliu, "Linearisation method and control for series active power filter by means of pulsewidth modulation,” IEE Proc.-Electr. Power Appl., Vol. 153, No. 3, May 2006

[5] G. Ramya , V. Ganapathy , P. Suresh "Power Quality Improvement Using Multi-level Inverter based DVR and DSTATCOM Using Neuro-fuzzy Controller" International Journal of Power Electronics and Drive System (IJPEDS), Vol. 8, No. 1, March 2017, pp. 316 324

[6] Akagi, H., Watanabe, E., and Aredes, M., "Hybrid and series active filters," in Instantaneous Power Theory and Applicationsto Power Conditioning, 1st ed., New Jersey:Wiley-IEEE Press,pp. 221-263, 2007.

[7] Cipriano dos Santos, E., Jacobina, C., Dias, J., and Rocha, N., "Single-phase to three-phase universal active power filter," IEEE Trans. Power Del., Vol. 26, No. 3, pp. 1361-1371, July 2011.

[8] Deshpande Chinmay V, Deshpande Chaitanya V, Deokar Sanjay A "Performance Evaluation of Dynamic Voltage Restorer Based on Transformer-based Z Source Inverter" International Journal of Power Electronics and Drive System (IJPEDS), Vol. 8, No. 3, September 2017, pp. 1101 1108

[9] Akagi, H., and Isozaki, K., "A hybrid active filter for a threephase12-pulse diode rectifier used as the front end of a mediumvoltagemotor drive, "IEEE Trans. Power Electron., Vol. 27, No.1, pp. 69-77, January 2012.

[10] Chaoui, A., Gaubert, J. P., Krim, F., and Champenois, G., "PI controlled three-phase shunt active power filter for power quality improvement," Electr. Power Compon. Syst., Vol. 35, No.12, pp. 1331-1344, September 2007.

[11] M. Salehifar, A. Shoulaie, "Voltage Quality Improvement by a Series Active Filter," International Conference for Technical Postgraduates (TECHPOS) Kuala Lumpur,Malaysia14-15 Dec. 2009

[12] O. ABDELKHALEK, A. KECHICH, C. BENACHIBA "Comparative Study between Two Topologies of an UPQC Six-Leg and an UPQC Seven-Leg" Electrotehnica, Electronica, Automatica,62 (4), 2014

[13] Wu Longhui, Zhuo Fang, Wang Zhaoan, "Soft Phase Locked Loop forActive Power Filter Applied in Small Rating Stand-alone Power System,’Power Elec. Specialists Conf., 2007. PESC 2007, Jun. 2007.

[14] F. D. Freijedo, J. Doval-Gandoy, O. Lopez and J. Cabaleiro, "RobustPhase Locked Loops Optimized for DSP Implementation in Power Quality Applications", Ind. Elec., IECON 2008. 34th Annual Conf.of IEEE, Nov.2008.

\section{BIOGRAPHIES OF AUTHORS}

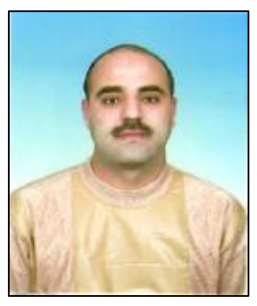

Benabdallah Abdelkader was born in Bechar, Algeria, in 1980. He received the L.Sc. degree in electrical engineering from Bechar University, Bechar, Algeria, in 2006 and M.Sc. degree in electrical engineering from University of Sciences and Technology of Oran (USTO) Algeria, in 2013, respectively, where he has been working toward the Doctoral degree in the Department of Electrical Engineering 2013. He is currently a Research Member in Smart Grids and Renewable Energies Lab, Department of Department of Electrical Engineering TAHRI Mohammed University Bechar Algeria. His main research activity is focused on FACTS Technology, Power System Control, Optimal Power Dispatch,

email:abdallahbenabdelkader@yahoo.fr,benabdelkader.abdallah@univ-usto.dz

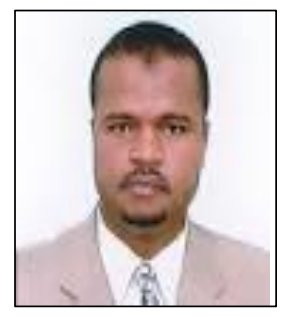

Othmane Abdelkhalek was born in Bechar (Algeria), on August 22, 1976.

He graduated in the University of Bechar, Department of Electrical Engineering (Algeria), in $2001 \mathrm{He}$ received the $\mathrm{PhD}$ degree in electrical engineering from the University of Bechar (Algeria), in 2010. He is a Professor at the University of Bechar. His research interests concern: power electronics, Power Quality, artificial intelligence and Power Systems. Correspondence address: Institute of science \&Technology, University of Bechar, BP 417 Route de Kenadsa, 08000 Bechar, Alegria;e-mail:Othmane_elec@yahoo.fr

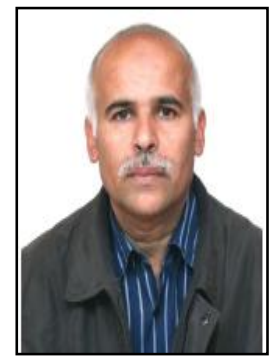

Ahmed Allali was born on 03.07.1960 in Mecheria Naama Algeria. In 1987 he graduated at the Electrotechnical Department of the Faculty of Electrical Engineering at University (USTO) in Algeria. He defended his "Magister". In the field of optimal power flow problems in 1990; his thesis title was "Optimal Distribution of Active Powers Using Linear Programming with Losses Cost Minimization", and the PhD degree from in 2006; His scientific research is focusing a control and real time simulation of power systems, and study of the Dynamic stability of the networks electrical supply. Actually he is interested in power electronics in particular to the facts and in renewable energies (wind and solar energy). He is currently Professor of electrical engineering at The University of USTO (Algeria) e-mail: allalia@yahoo.com 